\title{
Evaluating the Effectiveness of Grassbed Treatments as Habitat for Juvenile Black Bass in a Drawdown Reservoir
}

\author{
Donald R. RatclifF* ${ }^{1}$ and Wayne A. Wurtsbaugh \\ Department of Watershed Sciences and the Ecology Center, Utah State University, Logan, Utah 84322, USA
}

\author{
JOSEPH ZUSTAK \\ U.S. Department of Agriculture, Forest Service, Shasta-Trinity National Forest, \\ Redding, California 96003, USA
}

\begin{abstract}
Many reservoirs in arid regions experience highly variable water levels caused by seasonal inflow fluctuations and designated outflow requirements. At Shasta Lake, California, managers plant cerealgrain grassbeds on exposed drawdown shorelines to increase juvenile fish habitat, localize productivity, and increase invertebrate fish prey. To determine the efficacy of these plantings, the abundance of juvenile black basses Micropterus spp. (20-55 mm standard length) and the amount of periphyton and macroinvertebrate prey were compared among three treatment types: (1) planted grassbeds of cereal barley Hordeum vulgare; (2) artificial rope grassbeds, which eliminated physical deterioration and nutrient release; and (3) nonplanted control sites with predominately sand and gravel substrates. In comparison with control areas, juvenile black bass abundance averaged 54 times higher in planted grassbeds and 230 times higher in artificial grassbeds. Periphyton (chlorophyll $a$ ) and benthic invertebrate biomass did not differ significantly between planted grassbeds and control sites. In artificial grassbeds, periphyton was more than two times the control levels, and benthic invertebrate biomass was more than 12 times the control levels. We conclude that the long-term availability of physical structure, rather than nutrient release associated with decomposition of grassbed materials, drives use and effectiveness of grassbed treatments. Future management decisions in drawdown reservoirs should emphasize increasing long-term availability and integrity of physical habitat for juvenile fishes in the littoral zone.
\end{abstract}

Structurally complex lentic habitats can benefit juvenile fishes by providing refuges from predators and substrate for their prey organisms (Glass 1971; Savino and Stein 1982; Tabor and Wurtsbaugh 1991). Therefore, complex habitats are often used as nursery areas (Hall and Werner 1977), where survival of young fish may increase. In natural lakes, macrophyte beds and large woody debris from riparian areas often provide abundant areas of complex habitats (Mittelbach 1986; Schindler and Scheuerell 2002). However, in drawdown reservoirs, vegetation along the exposed shoreline is generally very limited because of highly variable fluctuations in water level, moderate to steep slopes, and relatively simple sediment composition. Summer reservoir drawdown may severely impact age0 fishes of many species by spatially reducing cover and feeding areas required by juvenile fish (Noble 1981). Turbidity from inflows and wave action on soils exposed by fluctuating water levels often limit attached

\footnotetext{
* Corresponding author: donald_ratcliff@fws.gov

${ }^{1}$ Present address: U.S. Fish and Wildlife Service, Anadromous Fish Restoration Program, 4001 North Wilson Way, Stockton, California 95205, USA

Received April 22, 2008; accepted December 29, 2008

Published online July 13, 2009
}

algae and aquatic macrophyte growth in reservoirs, thereby limiting areas where juvenile fish may find cover and food (Kimmel and Groeger 1984).

Artificial habitat has long been used as a fisheries management tool in areas where little natural habitat exists (Tugend et al. 2002). Artificial habitat structures have included conifer bundles (i.e., Christmas trees), brush piles, automobile tire bundles, rock cribs or cages, dowel stake beds, and substrate modifiers, such as gravel (Brown 1986). The primary goal of artificial habitat management has been to concentrate fish, improve cover for target fish species, and increase angler catch rates (Brown 1986). Fishing conditions in certain areas often improve for a limited time after artificial habitats are added, but analyses of these processes rarely address population-level growth.

Another common goal of artificial habitat, which has been widely ignored in most habitat assessments, is to increase fish survival by reducing predation or increasing food availability. Predation affects prey behavior and habitat selection (see reviews by Mittelbach and Chesson 1987; Lima and Dill 1990; Sih 1994). Similarly, predation by adult black basses Micropterus spp. is an important factor in determining survival and condition of juvenile black bass at Shasta Lake, California (J.Z., unpublished data). 
Our objective was to determine whether food availability, nutrient release, and habitat structure contributed to individual habitat selection and use by juvenile black bass in Shasta Lake. Specifically, we assessed areas where managers annually plant cerealgrain grassbeds on exposed drawdown shorelines to increase juvenile fish habitat, localize productivity, and increase invertebrate prey. To determine the efficacy of these plantings, we compared juvenile black bass (20$55 \mathrm{~mm}$ standard length) abundance and growth and the amount of periphyton and macroinvertebrate prey among three habitat types: (1) planted grassbeds of cereal barley Hordeum vulgare, (2) artificial grassbeds made of rope (eliminated physical deterioration and nutrient release characteristic of the cereal barley grassbeds), and (3) nonplanted control sites with predominately sand and gravel substrates.

\section{Methods}

Study area.-Shasta Lake is a 12,100-ha irrigation reservoir formed in 1944 with the completion of Shasta Dam $\left(40^{\circ} 43^{\prime} 07^{\prime \prime} \mathrm{N}, 122^{\circ} 25^{\prime} 04^{\prime \prime} \mathrm{W}\right)$. The dam is located on the Sacramento River (11 km upstream from Redding, California) and creates a full-pool reservoir elevation of $325 \mathrm{~m}$ above sea level. The lake has four major arms formed by the channels of the Pit, McCloud, and Sacramento rivers and Squaw Creek. At full pool, the reservoir contains $5.71 \mathrm{~km}^{3}$ of water, has a mean depth of $47 \mathrm{~m}$, and has $587 \mathrm{~km}$ of shoreline. Average surface water temperatures range from $10^{\circ} \mathrm{C}$ in winter to $28^{\circ} \mathrm{C}$ in summer, with thermal stratification generally beginning in June. Water temperature in Shasta Lake generally increases earlier in spring in the littoral zone than in the pelagic zone (J.Z., unpublished data). Mean annual reservoir drawdown is $21 \mathrm{~m}$; the maximum surface elevation usually occurs in May, and the minimum occurs in November. In 2004, drawdown between 1 May and 1 August was $18 \mathrm{~m}$, which is $6 \mathrm{~m}$ greater than the historical average.

The reservoir margins of Shasta Lake are generally moderately to steeply sloped and contain rocky, unproductive soils and very little natural vegetation. Natural topographic features, artificial habitat, and a limited number of inundation-tolerant plants (e.g., willows Salix spp.) create most cover in the reservoir. Less than $5 \%$ of the shoreline has inundated vegetation, even at full pool (J.Z., unpublished data). Therefore, that applicability of our results may be limited by individual lake characteristics and the unusually fast drawdown in 2004.

Warmwater fish species are found in the littoral zone of Shasta Lake; these primarily include spotted bass $M$. punctulatus, smallmouth bass $M$. dolomieu, and a limited number of largemouth bass $M$. salmoides.

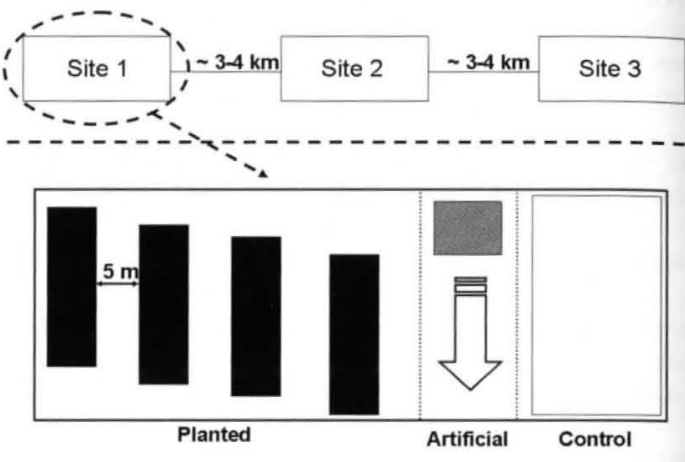

FIGURE 1.-Plan view of the spacing of three study sites in Shasta Lake, California, where the effects of littoral habitat manipulation on periphyton, invertebrates, and black bass were investigated in 2004; the treatment (planted grassbed [cereal barley], artificial grassbed [artificial lawn and polypropylene rope], and $5 \times 15-\mathrm{m}$ control [bare substrate]) layouts and dimensions are provided. The arrow in the artificial treatment box represents the relocation of habitat units (the shoreward row; row $=51-\mathrm{m}^{2}$ units) to follow the dropping water level and match the depth of the planted beds.

Through a cooperative agreement, the California Department of Fish and Game manages fish populations and the U.S. Forest Service manages fish habitat in Shasta Lake. The Pit River arm contains higher numbers of black bass and other littoral fish species than do other areas of the lake; therefore, the U.S. Forest Service has concentrated much of its effort in this area. Our study sites were located in the Pit River arm.

Study design.-We investigated whether planted grassbeds, artificial grassbeds composed of rope, and untreated control areas would influence periphyton, invertebrate abundance, and fish abundance (Figure 1). Three study sites, each with a planted grassbed treatment, artificial grassbed treatment, and control area, were monitored for 10 weeks (20 May to 30 July 2004). The three sites were about $3-4 \mathrm{~km}$ apart to ensure that replicates were independent.

To assess site-specific variance, water quality variables were routinely measured at each site. Temperature at each site was monitored hourly using Optic Stowaway temperature loggers (Onset Computer Corporation). Dissolved oxygen (DO) was measured twice per week using a DO probe (YSI Model 55; Yellow Springs Instruments), and water clarity was measured twice per week with a 20-cm Secchi disk.

Control area.-Control area substrates consisted of preexisting littoral zone material. The littoral zone of the lower Pit River arm of Shasta Lake has a mean surface area composition of $65 \%$ coarse gravel (16-64 $\mathrm{mm}), 25 \%$ fine gravel $(2-15 \mathrm{~mm}), 5 \%$ fine sediments 
$(<2 \mathrm{~mm})$, and less than $5 \%$ cobbles $(65-250 \mathrm{~mm})$ and boulders (251-4,000 mm; J.Z., unpublished data). Wind, drawdown action, and watercraft-driven waves frequently mobilize smaller sediments within the littoral zone, and subsequent settling leads to a high degree of embeddedness $(>70 \%)$. Interstitial spaces large enough for age-0 fish are rare (D.R.R. and J.Z., unpublished data).

Cereal barley grassbeds.-Areas to be planted were scarified using a harrow to create soil conditions acceptable for seeding. Equal proportions of cereal barley and fertilizer ( $\mathrm{N}: \mathrm{P}: \mathrm{K}=1: 1: 1$ by weight) were spread and then mulched with rice straw. This process was completed on 16 October 2003. Historical planting attempts showed that fertilizer was required for sprouting and growth from the grains. These grassbeds are planted annually and completely decompose each season after inundation.

After planting, grains sprouted and grew and were then inundated during April. Grass height at inundation averaged $21.7 \mathrm{~cm}($ range $=18-24 \mathrm{~cm})$. Each planted grassbed consisted of four strips $(5 \mathrm{~m}$ wide $\times 15 \mathrm{~m}$ long, with length being perpendicular to shore) separated by $5 \mathrm{~m}$ of open area. The first strip began $5 \mathrm{~m}$ below full pool elevation, and each successive strip started $3 \mathrm{~m}$ below the shoreward end of the previous strip (Figure 1). Due to rapid reservoir drawdown in 2004 , the lowest planted site was completely dewatered on 1 July 2004 (42 d after monitoring began).

Artificial grassbeds.-Artificial habitat treatments, constructed of polypropylene rope and artificial lawn (Astroturf), were placed in $15-\mathrm{m}^{2}$ patches $(3 \times 5 \mathrm{~m})$ at each site. Each artificial grass habitat patch was composed of 15 units made of $1-\mathrm{m}^{2}$ pieces of Astroturf wired to a welded rebar frame on the perimeter. Artificial stems were created by attaching 195 sections of yellow, three-strand polypropylene rope (20-25 cm long, $1.5-\mathrm{cm}$ diameter) through small holes in the Astroturf. These rope sections were knotted on both sides of the hole and were unwound above the Astroturf to mimic grass. The number and length of stems per unit were based on previous measurements from planted grass treatments.

A patch was deployed at each replicate site (5-m axis was parallel to shore; $3-\mathrm{m}$ axis was perpendicular to shore). The upper one or two rows (of the three rows) of artificial grass habitat were moved to the deeper row of the patch each week after deployment; this was done to follow the dropping water level of the lake and to match the depth of the planted bed section to be surveyed on each sampling date.

Fish abundance.-Fish abundance was estimated using scuba surveys; within each treatment and control area, three depth transects $(1.2,2.2$, and $3.0 \mathrm{~m})$ were sampled on each sample date. Secchi depth was measured before diving began, and diving was postponed when Secchi depth was less than $1.8 \mathrm{~m}$. During the dive survey, two divers entered the water and approached the habitat and depth to be surveyed (one diver enumerated fish; the second diver was present as a safety precaution). Once they reached the habitat area, the divers rested near the bottom for 3-5 min to allow effects of their presence to dissipate. One diver then swam a 5-m-long transect crossing the habitat bed and parallel to shore and recorded the number and species (where possible) of fish encountered within a 3-m-wide swath (to visually estimate a 3$\mathrm{m}$-wide swath, the diver carried a 3-m piece of wooden dowel and centered it over the transect). After reaching the end of a transect, the diver waited 3-5 min and then returned along the same transect to note all fish that were encountered. This process was repeated at the three depths for each habitat type. Fish counts were averaged for both passes at each depth. When more than one of the four planted grassbed strips was inundated at the given depth to be sampled, we randomly selected the strip to be surveyed; at the planted grassbeds, we also approximated stem height and general plant condition during the fish surveys.

Juvenile black bass were counted as a single group because specific identification was not consistently possible due to the small size of individuals, the time required to identify individual fish at the species level, and visibility. Smallmouth bass juveniles that could be positively identified to species were slightly larger (25$55 \mathrm{~mm}$ standard length) than juveniles of other bass species $(20-50 \mathrm{~mm}$ standard length). Adult spotted bass (150-400 mm standard length) and smallmouth bass (200-350 $\mathrm{mm}$ standard length) were observed at all sites at least once; however, they were never observed in significant numbers at any site and were often not present on a given date or site. No adult largemouth bass were observed.

Periphyton biomass sampling.-Benthic periphyton (algae) was measured by taking core samples on 17 June, 12 July, and 30 July 2004. One core was taken from a random point along each of the three fish survey depth transects within each treatment type at each site. Core samples at planted grass and control sites were collected using a 7.6-cm-diameter slurp gun (suction collecting device used by commercial tropical fish collectors; Model HA66; Trident Diving Company). The slurp gun was pushed $3 \mathrm{~cm}$ into the substrate. The plunger of the slurp gun was then drawn up $40 \mathrm{~cm}$, and a metal plate was pushed over the end of the tube to retain the sample. The cores collected from the planted treatments included grass blades and roots up to $3 \mathrm{~cm}$ deep. 
A different technique was used for artificial grass treatments because strands of polypropylene rope jammed the slurp gun. At each artificial grass site, nine circular (7.6-cm-diameter) pieces of Astroturf and rope were attached to individual habitat units among the 15 units that were used to create each complete treatment. On each sampling date, one of the three attached pieces at each depth was randomly collected from each artificial treatment. Pieces were collected using a polyvinyl chloride tube $(40 \mathrm{~cm}$ long, $7.6-\mathrm{cm}$ diameter) placed over the selected habitat piece. The piece was then disconnected from the artificial habitat unit, and a metal plate was placed over the end of the tube to retain the sample. All collected core samples were placed on ice in plastic bags and frozen within $3 \mathrm{~h}$ of collection.

Periphyton biomass was estimated by extracting and quantifying chlorophyll $a$. All liquid associated with core samples was filtered through a grade-391 glassfiber filter (Baxter Scientific Products). The filters and the solids from the core were then frozen. Solid material from benthic core samples was thawed, and a premeasured amount of deionized water was added. The sample was then vigorously agitated for $60 \mathrm{~s}$ to remove attached periphyton before being filtered through a grade-391 glass-fiber filter. Filters from each sample (one from the liquid and one from the solid portion of the sample) were then placed for $24 \mathrm{~h}$ in $95 \%$ ethanol in the dark, and extracted chlorophyll was analyzed fluorometrically via Welschmeyer's (1994) method. Liquid and solid portions of chlorophyll- $a$ weight for each benthic core sample were combined and scaled $\left(\mu \mathrm{g} / \mathrm{cm}^{2}\right)$ to the $45-\mathrm{cm}^{2}$ area sampled.

Zooplankton density and invertebrate biomass sampling.-During the 10-week study period, zooplankton samples were collected once every 2 weeks at each habitat type by divers using a 20 -cm-diameter net with $80-\mu \mathrm{m}$ mesh towed along one of the fish abundance transects at each treatment. The plankton net had a $0.3-\mathrm{m}$ piece of rope attached to the mouth so that the diver could keep the net $0.3 \mathrm{~m}$ off of the substrate. The zooplankton samples were fixed with Lugol's solution.

Subsamples of at least 200 individuals were counted with a dissection microscope at $30 \times$ magnification and identified to genus using taxonomic keys (Pennak 1989). Lengths of up to 20 individuals from each taxon in the subsample were measured with a micrometer. Biomass was estimated using literature-based lengthweight regression equations for each taxon (Table 1). Areal biomass of zooplankton was then estimated by multiplying biomass (weight per volume) for each tow by the depth of the water column for individual tows.
TABLE 1.-Weight-length regression parameters used to calculate dry weight of invertebrate biomass in Shasta Lake, California, 2004. The general weight-length formula, $\log _{e}$ (dry weight, $\mathrm{mg}$ ) $=\log _{e} a+b \log _{e}$ (length, mm), was used, where $a$ and $b$ are constants for each species. Sources are (A) Downing and Rigler (1984), (B) Benke et al. (1999), (C) Wurtsbaugh and Hawkins (1990), and (D) Lemke and Benke (2004). The equation for Hyalella azteca is based on head capsule length rather than total length.

\begin{tabular}{lcll}
\hline \multicolumn{1}{c}{ Taxon } & Source & \multicolumn{1}{c}{$a$} & \multicolumn{1}{c}{$b$} \\
\hline Daphnia pulex & A & 0.0012 & 2.63 \\
Nauplii & $\mathrm{A}$ & 0.0021 & 0.469 \\
Leptodora spp. & $\mathrm{A}$ & 0.00044 & 2.67 \\
Calanoida & $\mathrm{A}$ & 0.00347 & 2.2431 \\
Cyclopoida & $\mathrm{A}$ & 0.00927 & 3.23 \\
Harpacticoida & $\mathrm{A}$ & 0.003542 & 2.1512 \\
Hyalella azteca & $\mathrm{B}$ & 1.4134 & 2.839 \\
Caenis spp. & $\mathrm{B}$ & 0.0033 & 2.924 \\
Chironomidae & $\mathrm{B}$ & 0.0051 & 2.322 \\
Ceratopogonidae & $\mathrm{B}$ & 0.00022 & 2.871 \\
Oecetis spp. & $\mathrm{B}$ & 0.0034 & 3.212 \\
Ostracoda & $\mathrm{C}$ & 0.040 & 1.19 \\
Annelida & $\mathrm{C}$ & 0.0037 & 1.00 \\
Eurycercus spp. & $\mathrm{D}$ & 0.013 & 2.62 \\
\hline
\end{tabular}

Benthic invertebrates were sampled using a vacuum pump sampler similar to that used by Voshell et al. (1992). The sampler consisted of an inverted 11.4-L plastic bucket with a port and glove attached to the side of the bucket so that a diver could agitate the substrate. An inlet hose and a hand-powered vacuum pump (Guzzler model; U.S. Plastics Corporation) were attached to the bucket so that the sample could be collected with a net attached to the dive boat. A diver placed the bucket over the sampling area and then agitated the substrate for $30 \mathrm{~s}$. The diver then released a float to advise the observer to start the pump. All water initially in the hose (between the bucket and the pump) was cleared from the line, and an 11.4-L sample was then pumped through a $70-\mu \mathrm{m}$ sieve. Four random samples were collected from each treatment type at each site on three separate dates. Samples were fixed in $70 \%$ ethyl alcohol for processing.

Processing involved dividing the sample through a series of progressively smaller screens, removing macroinvertebrates within each sample, and identifying individuals to the lowest possible taxonomic level (taxonomic keys in Merritt and Cummins 1996). Lengths of up to 50 individuals from each taxon in the subsample were measured with a micrometer. After processing, benthic macroinvertebrate biomass was calculated using weight-length regressions (Table 1).

Black bass diet and proximate food availability sampling.-Juvenile black bass were collected on 12 and 28 July 2004 from the three study sites plus two randomly selected sites near Shasta Dam (about $9 \mathrm{~km}$ from the study sites) so that general condition and diet 
of fish sampled from nontreated areas of the lake could be compared with those of fish at the study sites. We collected 90 fish on each sampling date (5 fish from each of three control areas; 5 fish from each of three artificial grassbed areas; and 30 fish from each random site near Shasta Dam). Fish were collected opportunistically with a slurp gun at a depth of $1.5-3.5 \mathrm{~m}$. Individual prey items were identified from stomach contents of each fish.

Benthic invertebrates in close temporal and spatial proximity to the collected black bass were simultaneously sampled at all study sites. Four random benthic invertebrate samples were collected at each treatment area ( 8 samples/study site), and 12 random samples were collected at each Shasta Dam site. Finally, a feeding electivity index (Ivlev 1961) was used to estimate differences in food availability and use among treatment types and study sites.

Statistical analysis.-Data analyses were completed using the Statistical Analysis System (SAS) version 8.2 for Windows (SAS Institute 2001). All assumptions necessary for analysis of variance (ANOVA) were examined for individual analyses, and none of the data needed transformation. When appropriate, post hoc means comparisons were completed via a Ryan-EinotGabriel-Welsch multiple range (REGWQ) test.

The site characteristics of water temperature, Secchi depth, and DO were compared using separate twofactor ANOVAs for each variable. In all three tests, treatment type and date were the independent variables, and the measured site characteristic was the dependent variable.

Fish abundance was compared among treatments using a two-way factorial ANOVA with time as a categorical factor. A split-plot design was used instead of a repeated-measures design because transect locations changed weekly (transects were located by depth because of water level fluctuation). Treatment type and date were the independent variables, and observed fish abundance was the dependent variable.

A two-step procedure was needed to assess treatment effects on periphyton, zooplankton, and benthic invertebrates because the planted grassbeds were not inundated after 1 July, whereas comparisons could be continued for the artificial grassbeds and control substrates. Consequently, the abundances of each trophic group on the first sampling date were compared with single-factor ANOVAs, where treatment type was the independent variable and periphyton, zooplankton biomass, or invertebrate abundance was the dependent variable. Two-factor ANOVAs with treatment type and date as independent variables and the abundances of each trophic group as the dependent variables were used to compare abundances between artificial grassbeds and control areas on all of the sampling dates.

Invertebrate species that were consumed at levels exceeding or equal to their environmental availability were individually compared between artificial grassbeds and control areas on all three sampling dates. A two-factor ANOVA was completed for each species; sampling date and treatment were independent variables, and species-specific biomass was the dependent variable. Finally, two separate two-factor ANOVAs were completed to compare macroinvertebrate availability and fish diet based on data from this study and auxiliary data gathered for a separate growth study at two nontreatment sites (Ratcliff 2006). Macroinvertebrate availability and fish diet each served as the dependent variable in one of the tests, and site and date were the independent variables for both tests.

\section{Results}

\section{Site Characteristics}

Water temperature, Secchi depth, and DO were similar among treatments. Surface water temperature increased from $22.3^{\circ} \mathrm{C}$ to $30.0^{\circ} \mathrm{C}$ during the season but was relatively consistent among sites on each date $\left(F_{2,52}=0.048, P=0.95\right)$. Temperatures at $3 \mathrm{~m}$ were consistently $0.2-0.4^{\circ} \mathrm{C}$ cooler than temperatures at the surface. Secchi depth ranged from 1.3 to $3.9 \mathrm{~m}$ but did not vary significantly among treatments on any date $\left(F_{2.54}=0.001, P=0.99\right)$. Oxygen levels were consistently greater than $7.5 \mathrm{mg} / \mathrm{L}$ but did not differ detectably among sites on any date.

At the start of the assessment on 24 May 2004, average stem height of planted grass was $21.7 \mathrm{~cm}$, similar to the height of artificial grass treatments (22.2 $\mathrm{cm})$. Between 24 May and 14 June 2004, 85\% of individual grass stems appeared upright but lost about $2.1 \mathrm{~cm}$ in height each week (Figure 2a). During this period, planted and artificial grassbeds were similar in physical structure when observed underwater. From 15 to 30 June 2004, planted grass stems lost about $4 \mathrm{~cm}$ in height each week and averaged only $4 \mathrm{~cm}$ in height by the end of the month, when falling water levels exposed plantings. During this period, more than $90 \%$ of individual stems laid flat along the substrate and were increasingly covered by fine sediment. By the time planted grassbeds were no longer inundated, more than $90 \%$ of individual plants were decomposed beyond the point where they could be identified above the sediments.

\section{Juvenile Black Bass Abundance}

Age- 0 black bass began using dense cover habitats between the last week of May and the first week of June. Fish were closely tied to dense cover until mid- 

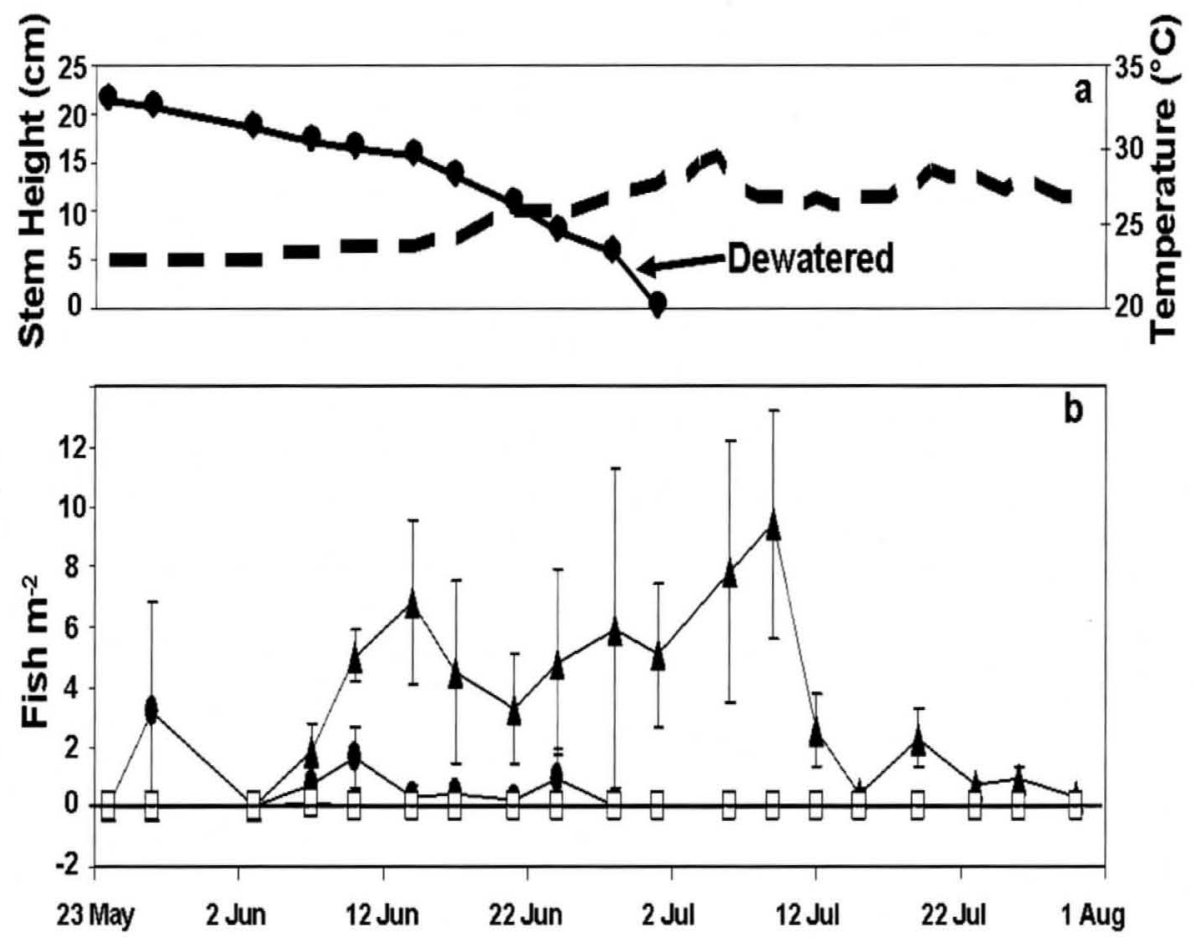

Figure 2.-(a) Average stem height (cm; black circles) and surface water temperature $\left({ }^{\circ} \mathrm{C}\right.$; dashed line) in cereal barley grassbeds planted in Shasta Lake, California, 2004; and (b) juvenile black bass density (fish $/ \mathrm{m}^{2} ; \pm 95 \%$ confidence interval) in three experimental habitat treatment types: planted grassbeds (black ovals), artificial grassbeds (black triangles), and control areas (open squares).

July and then dispersed in small groups or individually to other local areas with larger-scale habitat features (constructed brush structures, natural topographic features, and willows). Fish abundance did not differ between transect depths, so data collected over all depths at each treatment were pooled for subsequent analyses. Between 27 May and 28 June 2004, mean juvenile bass density in planted grassbeds ( 0.750 bass/ $\left.\mathrm{m}^{2}\right)$ was 54 times the density in control areas $(0.014$ bass $\left./ \mathrm{m}^{2}\right)$; density in artificial grassbeds (3.25 bass $/ \mathrm{m}^{2}$ ) was 232 times that in control areas. Densities in all three treatment areas were significantly different from each other (ANOVA: $F_{2,18}=10.11, P=0.001$; for REGWQ at $\alpha=0.05$, all means were significantly different).

Juvenile black bass were generally observed hovering and actively feeding near tops and directly above grasses and ropes in planted and artificial treatment sites (17-30 $\mathrm{cm}$ above the substrate). In control areas, juvenile bass generally held near areas of available structure $(2-10 \mathrm{~cm}$ above the substrate, usually in close proximity to small rocks or other small-scale hiding habitat) and were rarely seen feeding. Juveniles moved closer to the substrate and held between individual grass stems or ropes $(3-10 \mathrm{~cm}$ above the substrate) when adult bass were moving near or over the planted or artificial grassbeds. Adult bass generally held near edges of planted and artificial grassbeds near the substrate $(5-20 \mathrm{~cm}$ above the substrate). Adult fish occasionally swam above treatment areas but were generally hesitant to remain there (typically stayed for $<30 \mathrm{~s}$ ) or to move close to grasses or ropes (adult fish were never observed closer than $30 \mathrm{~cm}$ above the substrate when they were above the planted and artificial treatments).

\section{Algal Biomass}

On the first algal sampling date (17 June), mean chlorophyll- $a$ levels of periphyton in artificial grassbeds $\left(0.23 \mu \mathrm{g} / \mathrm{cm}^{2}\right)$ were two to three times those in planted grassbeds $\left(0.09 \mu \mathrm{g} / \mathrm{cm}^{2}\right)$ and control areas $\left(0.11 \mu \mathrm{g} / \mathrm{cm}^{2}\right.$; Figure 3$)$. Chlorophyll- $a$ concentrations in planted grassbeds and control areas did not differ significantly but were both marginally lower than those in the artificial grassbeds (ANOVA: $F_{2,6}=4.29, P=$ 0.069 ; REGWQ grouping at $\alpha=0.05$ : group $\mathrm{A}=$ artificial, group $\mathrm{B}=$ planted and control). Mean chlorophyll- $a$ concentrations in artificial grassbeds 


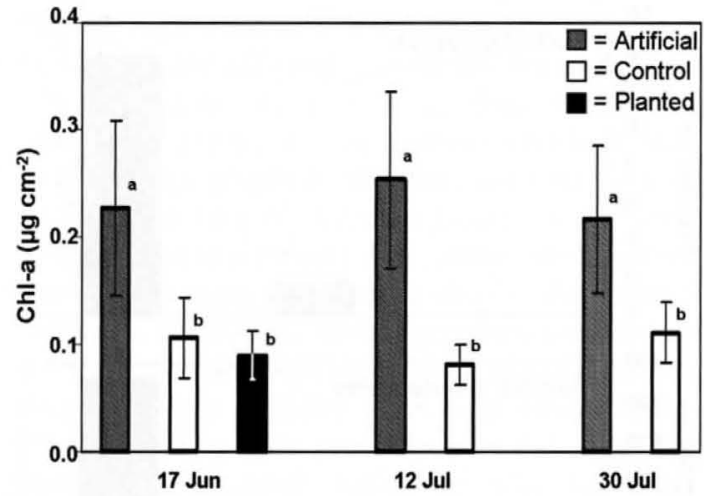

FIGURE 3.-Chlorophyll- $a$ levels (chl- $a ; \mu \mathrm{g} / \mathrm{cm}^{2} ; \pm 95 \%$ confidence interval) of periphyton (primarily algae) in three habitat treatment types (planted cereal barley grassbeds, artificial grassbeds, and control areas) on three sampling dates in Shasta Lake, California, 2004. For a given date, treatments with different letters were significantly different. After 1 July, reservoir water levels declined below the lowest planted grassbeds, so chlorophyll $a$ could not be measured for that treatment type.

$\left(0.232 \mu \mathrm{g} / \mathrm{cm}^{2}\right)$ were significantly higher than those in control sites $\left(0.099 \mu \mathrm{g} / \mathrm{cm}^{2}\right)$ until the end of July $\left(F_{1,16}\right.$ $=22.71, P<0.001)$. Algal biomass did not vary significantly among sampling dates $\left(F_{2,15}=1.08, P=\right.$ $0.365)$.

\section{Zooplankton Density}

During June, zooplankton areal biomass in artificial grassbeds $\left(4.33 \mathrm{mg} / \mathrm{m}^{2}\right.$; Figure 4$)$ was approximately four times the biomass in planted grassbeds $(0.77 \mathrm{mg} /$

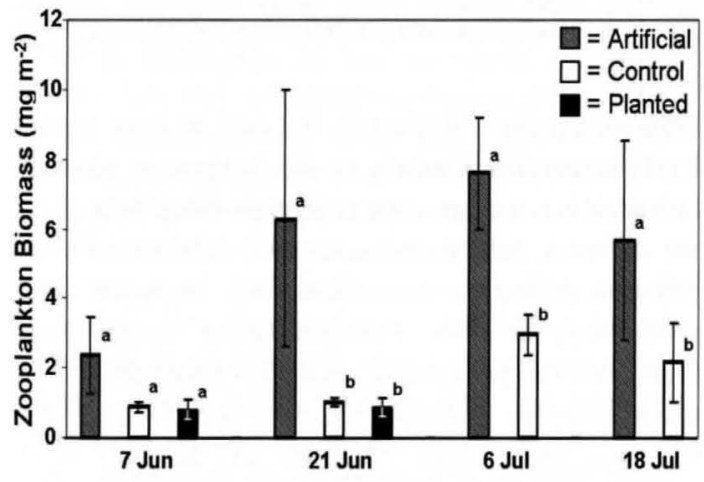

FIGURE 4.-Zooplankton areal density $\left(\mathrm{mg} / \mathrm{m}^{2} ; \pm 95 \%\right.$ confidence interval) in three habitat treatment types (planted cereal barley grassbeds, artificial grassbeds, and control areas) on four sampling dates in Shasta Lake, California, 2004. For a given date, treatments with different letters were significantly different. After 1 July, reservoir water levels declined below the lowest planted grassbeds, so zooplankton could not be sampled for that treatment type.

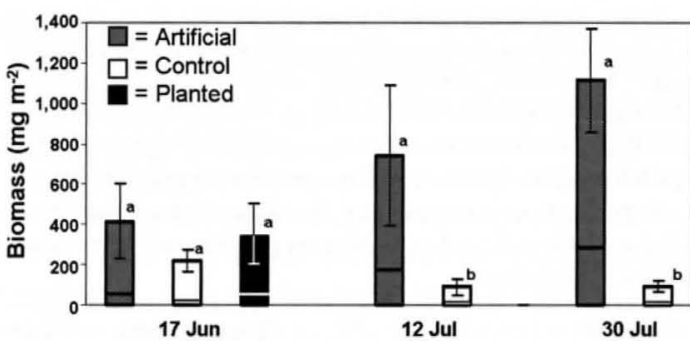

FIGURE 5.-Benthic invertebrate biomass $\left(\mathrm{mg} / \mathrm{m}^{2} ; \pm 95 \%\right.$ confidence interval) in three habitat treatment types (planted cereal barley grassbeds, artificial grassbeds, and control areas) on three sampling dates in Shasta Lake, California, 2004. Area below the horizontal lines within each bar represent the estimated biomass of Hyalella azteca. For a given date, treatments with different letters were significantly different. After 1 July, reservoir water levels declined below the lowest planted grassbeds, so benthic invertebrate biomass could not be measured for that treatment type.

$\left.\mathrm{m}^{2}\right)$ and control areas $\left(0.90 \mathrm{mg} / \mathrm{m}^{2}\right)$. Biomasses in planted grassbeds and control areas did not differ significantly, but they were significantly lower than the biomass in artificial grassbed areas $\left(F_{2,15}=7.82, P=\right.$ 0.004; REGWQ grouping at $\alpha=0.05$ : group $\mathrm{A}=$ artificial, group $\mathrm{B}=$ planted and control). Mean zooplankton biomass in artificial grassbeds $(5.48 \mathrm{mg} /$ $\left.\mathrm{m}^{2}\right)$ remained three times that in control areas $(1.73$ $\left.\mathrm{mg} / \mathrm{m}^{2}\right)$ until the end of July $\left(F_{1,22}=19.12, P<\right.$ 0.001 ).

The zooplankton community was dominated by two cladoceran genera-Eurycercus and Daphnia-across all treatments and dates. Eurycercus made up $41 \%$ of the total number of zooplankton; their average density was 0.31 individuals $/ \mathrm{L}(\mathrm{SE}=0.06, N=30$ ) and average length was $0.5 \mathrm{~mm}(\mathrm{SD}=0.2, N=100)$. Daphnia made up $35 \%$ of the total number of zooplankton; their average density was 0.23 individuals $/ \mathrm{L}(\mathrm{SE}=0.04, N=30)$ and average length was 0.7 $\mathrm{mm}(\mathrm{SD}=0.2, N=100)$.

\section{Benthic Invertebrate Biomass}

During June, benthic invertebrate biomass did not differ significantly among treatments $\left(F_{2,33}=1.62, P=\right.$ 0.213; Figure 5). In July, benthic invertebrate biomass in artificial grassbeds was 12 times the biomass in control areas $\left(F_{1,34}=10.97, P<0.001\right)$. Hyalella azteca (Amphipoda) was prominent in artificial grassbeds, and other abundant invertebrates included Caenis spp. (Ephemeroptera), Eurycercus, and several species of Ostracoda.

Hyalella azteca biomass significantly increased over time $\left(F_{2,14}=6.22, P=0.017\right)$ and was significantly higher $\left(F_{1,15}=36.55, P<0.001\right)$ in artificial grass 
TABLE 2.-Ivlev's (1961) electivity index, $\left(R_{i}-P_{i}\right) /\left(R_{i}+\right.$ $P_{i}$ ), for food items in diets of free-ranging black bass in Shasta Lake, California, during 2004, where $P_{i}$ is the relative abundance proportion of a taxon in environmental samples and $R_{i}$ is the relative abundance proportion of a prey taxon in black bass diets. Index values range from complete avoidance $(-1)$ to complete selection $(+1)$. We assumed that values from -0.2 to +0.2 indicated consumption proportional to environmental availability.

\begin{tabular}{lcccr}
\hline \multicolumn{1}{c}{ Taxon } & $P_{i}$ & $R_{i}$ & Electivity index & Rank \\
\hline Oecetis spp. & 0.007 & 0.082 & 0.83 & 1 \\
Chironomidae & 0.082 & 0.388 & 0.65 & 2 \\
Eurycercus & 0.093 & 0.115 & 0.11 & 3 \\
Hyalella azteca & 0.118 & 0.111 & -0.03 & 4 \\
Caenis spp. & 0.463 & 0.277 & -0.25 & 5 \\
Daphnia spp. & 0.045 & 0.019 & -0.41 & 6 \\
Ostracoda & 0.191 & 0.006 & -0.94 & 7 \\
\hline
\end{tabular}

treatments than in control areas. Biomass of Eurycercus decreased significantly over time $\left(F_{2,14}=16.40, P\right.$ $<0.001)$ and was significantly higher in the artificial grassbeds than in the control areas $\left(F_{1,15}=8.89, P=\right.$ 0.009). Oecetis spp. (Trichoptera) biomass decreased significantly over time $\left(F_{2,14}=52.43, P<0.001\right)$ and did not differ significantly among treatments $\left(F_{1,15}=\right.$ $3.28, P=0.092$ ). Biomass of Chironomidae (Diptera) decreased significantly over time $\left(F_{2.14}=14.65, P<\right.$ $0.001)$ and was significantly higher in control areas than in artificial grassbeds $\left(F_{1,15}=126.4, P<0.001\right)$.

\section{Black Bass Diet versus Proximate Food Availability}

Invertebrate availability did not significantly differ between dates $\left(F_{1.95}=2.56, P=0.113\right)$ or between experimental and random (Shasta Dam) sites $\left(F_{2,46}=\right.$ $1.87, P=0.166$ ). Fish diet did not significantly differ between dates $\left(F_{1,179}=2.12, P=0.147\right)$ or between experimental and random sites $\left(F_{2,88}=1.41, P=\right.$ 0.249 ). Therefore, data from both areas were combined. Benthic invertebrates made up $86 \%$ of black bass diets, and epibenthic Eurycercus represented an additional $12 \%$ of the prey consumed (Table 2). Zooplankton (primarily Daphnia) represented only $2 \%$ of the diet. Two less-abundant invertebrate taxa, Oecetis spp. and chironomids, were consumed at higher rates than their availability in the environment. Of the four most abundant invertebrates, Eurycercus and $H$. azteca were consumed at about the same rate at which they were available in the environment, whereas Caenis spp. and ostracods were very abundant but rarely consumed by juvenile black bass.

\section{Discussion}

We documented increased juvenile black bass abundance, periphyton biomass, and benthic invertebrate biomass in grassbed treatments, particularly in
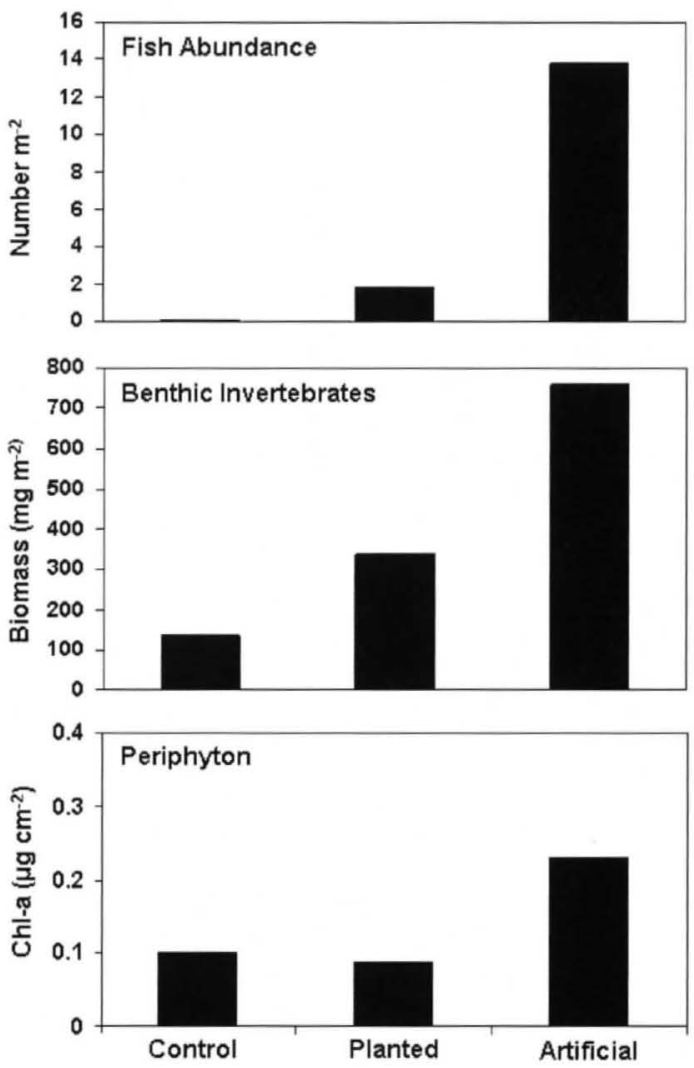

FIGURE 6.-Summary of juvenile black bass abundance (fish $/ \mathrm{m}^{2}$; average for 7-28 June), benthic invertebrate biomass $\left(\mathrm{mg} / \mathrm{m}^{2}\right.$; average for $10 \mathrm{June}, 15 \mathrm{July}$, and 2 August; planted grassbed: 10 June only), and attached algal biomass (chlorophyll $a$ [chl- $a$ ], $\mu \mathrm{g} / \mathrm{cm}^{2}$; average for 17 June, 12 July, and 30 July; planted grassbed: 17 June only) for three habitat treatment types (planted cereal barley grassbeds, artificial grassbeds, and control areas) in Shasta Lake, California, 2004.

artificial grassbeds (Figure 6). Because all three trophic levels responded similarly to the increase in physical habitat, it is not clear whether juvenile black bass chose the complex habitats because such habitats afforded physical protection from predators, increased food availability, or both. However, other studies have found that the presence of predators forces the use of these complex habitats (Savino and Stein 1982; Gotceitas and Colgan 1989; He and Kitchell 1990; Tabor and Wurtsbaugh 1991; Diehl and Eklov 1995; Chick and McIvor 1997). Additionally, small forage fish have been observed to feed offshore on zooplankton but to utilize shoreline cover during the day where feeding is limited (Werner et al. 1983; Wurtsbaugh and $\mathrm{Li}$ 1985). These results suggest that the physical structure provided by planted grassbeds and the 
artificial rope treatments may have been the most important factor attracting juvenile black bass.

It was surprising that black bass usage was significantly greater for the artificial grassbeds than for the planted grassbeds. This may have been due to the increased ratio of perimeter to area in the small artificial grassbeds (Jelbart et al. 2006). We observed juvenile bass using all perimeter areas of the artificial treatments, whereas the planted grassbeds provided up to $50 \%$ less of this edge habitat (i.e., artificial patches always had four available edges at preferred depths, while planted grasses generally provided only two edges). Fish frequently utilize the edge habitat of patches, and small patches therefore have higher densities per unit area than do large expanses of cover, such as those in the planted grassbeds. However, the relationship between patch size, edge effects, habitat complexity, and fish size and use are complicated (Horinouchi 2007), making it difficult to design optimal habitats for fish.

Although juvenile black bass used artificial grassbeds more than the planted grassbeds, the latter was still used far more than the control areas; however, this difference disappeared rapidly as the planted grasses decomposed and the grassbeds became dewatered. Consequently, the planted grassbeds only provided effective habitat for about 1 month in the $20-25^{\circ} \mathrm{C}$ waters of Shasta Lake, whereas the more durable artificial plastic ropes continued to attract fish for at least 2 months. Longer-lived structures might therefore be preferable to planted grassbeds. However, monitoring of other cost-effective habitat treatment types (e.g., conifer bundles, brush piles, and rock cribs) in Shasta Lake has shown limited use by juvenile fish (D.R.R. and J.Z., unpublished data). Furthermore, these types of habitat treatments are not commonly focused on juvenile fish and are often implemented to address habitat limitations for adult fish (Brown 1986). However, habitat improvements of differing composition will probably be used at different rates by juveniles of different fish species, and treatments need to be implemented for specific target species. For example, Tabor and Wurtsbaugh (1991) found that juvenile rainbow trout Oncorhynchus mykiss in a reservoir used complex littoral habitat like boulders and inundated willows but avoided submerged macrophytes.

The differences we documented at multiple trophic levels between planted and artificial grassbeds showed that nutrient release from grasses was not important in driving juvenile black bass abundance, primary production, or benthic invertebrate biomass. Cumulative positive effects might have occurred because of increased nutrient release if grasses were planted on a larger scale, but we did not address such effects. Our findings suggest that primary producers and grazers would not realize long-term benefits from decomposition of planted grasses. Inundation of vegetation and hypothesized increases in nutrient release after newly constructed reservoirs are filled are frequently cited as a reason for early peaks in fish production (Ney 1996), but rigorous tests of this hypothesis are lacking. Other hypotheses, such as changes in trophic cascades as a reservoir matures, also need to be considered (Hrbáček et al. 1961; Tatrai et al. 1998).

Juvenile black bass collected in Shasta Lake fed on benthic and epibenthic prey rather than zooplankton (Ratcliff 2006). In our study, even though zooplankton density in artificial habitats was three times the density observed over untreated substrates, areal densities remained low. If age- 0 fish foraged up to $0.5 \mathrm{~m}$ above the substrate, then the maximum zooplankton areal density available in treated areas would have been 7.5 $\mathrm{mg} / \mathrm{m}^{2}$; in contrast, benthic invertebrate biomass in treated areas reached $100-1,100 \mathrm{mg} / \mathrm{m}^{2}$. Zooplankters were also smaller than benthic invertebrates. For many species of zooplankton, areal density is more likely driven by pelagic processes in the lake and life history characteristics of individual species (Dodson and Frey 1991) than by local benthic habitat characteristics. However, benthic invertebrate biomass (including Eurycercus, an epibenthic zooplankter) generally increased with the addition of dense cover to the littoral zone. Our findings agreed with those from other systems, where higher plant densities created higher densities of benthic invertebrate prey (Gerrish and Bristow 1979; Wiley et al. 1984) and where benthic invertebrates constituted the predominate prey of many fishes (Vadeboncoeur et al. 2002). Because of the dewatering of planted sites, benthic invertebrate samples could not be collected across multiple dates, so we were not able to determine whether increased invertebrate biomass in artificial grassbeds was due to increased physical structure or increased algal abundance. Benthic invertebrate biomass was also probably affected by life history differences among taxa. To fully address differences in benthic invertebrate biomass, differences in mobility, emergence, feeding habits, and other taxa-specific variables would need to be measured.

\section{Management Implications}

Habitat manipulation addressing juvenile fish at Shasta Lake and other reservoirs should investigate (1) the longevity of planted grassbeds; (2) the impacts on localized water quality and aquatic production; and (3) the amount of use that habitat treatments might receive from target fish species. If longer-lasting material were used in large-scale habitat treatments, juvenile black 
bass would probably use habitats extensively for predation avoidance. Our study also showed that longer-lasting habitat treatments could provide an increase in local productivity and could concentrate food organisms long enough for juvenile black bass to use. However, a growth study of black bass caged within artificial habitats suggested that neither planted nor artificial grass treatments increased growth rates above those of fish held in control habitat (Ratcliff 2006). This suggests that the structure provided by habitat, rather than increased food production, is most important for age-0 fish.

Artificial grassbeds in our study were not meant to be a long-term habitat treatment for use in management but instead were designed to mimic physical structure provided by planted grassbeds while eliminating effects of grass decomposition and possible nutrient release. Supply costs for planted grassbeds are less than US\$2,200 per hectare, and grassbeds can be planted quickly with general laborers and do not require maintenance once planted. Conversely, artificial grassbeds cost up to 20 times more per area treated, involve intensive construction labor, and require regular monitoring and possible movement to track changes in water levels. Although positive results may be temporally limited in comparison with artificial grassbeds, planted grassbeds provide a cost-effective way to treat large areas. More emphasis needs to be given to developing planting strategies (i.e., layout of planted beds, different plant species, or multiple plant species) that will prolong the life of planted grassbeds.

The findings from our artificial grassbeds may be most applicable to smaller ponds, reservoirs, and lakes that experience significant seasonal drawdown and where treatments could impact a significant portion of the available shoreline. The large and variable amount of littoral area contained within reservoirs like Shasta Lake requires habitat treatments to be easily implemented and cost effective on a much larger scale than the treatments used in our study.

Finally, to completely assess the effect of habitat treatments on fish populations, fish densities must be monitored until the target species reach catchable size. In Shasta Lake, population estimates are not completed by management agencies, so the long-term effect of habitat modifications could not be evaluated. Consequently, although we documented local and short-term effects of habitat manipulations on segments of the black bass population, more research is needed to determine effects of such treatments on entire populations.

Based on our findings, desirable attributes for habitat treatments in drawdown reservoirs include the following: (1) treatments should be available and remain productive while the limited mobility of juvenile fish makes them susceptible to predation (mid-May through July in Shasta Lake), (2) ease of implementation should be considered so that large areas can be treated in a cost-effective manner, (3) treatments should be implemented in a way that does not compromise other life history stages or other desirable species, (4) treatments should be accessible to littoral-zone-dependent fishes over a wide range of reservoir water-level elevations and drawdown scenarios, and (5) treatments should be monitored for effectiveness with regard to populationlevel impacts. Similar habitat attributes should be addressed when designing appropriate habitat treatments for both yearling and older black bass ageclasses in other lakes, ponds, and impoundments that experience seasonal water level fluctuations and limited complexity within littoral zone habitats.

\section{Acknowledgments}

Jacie Knight, Gaylon Wilcox, and Kevin Hansen provided field and laboratory assistance. Jennifer Gervais and Jeff Kershner reviewed the manuscript. Funding for this study was provided by the U.S. Forest Service and the Utah State University Ecology Center. Reference to trade names does not imply endorsement by the U.S. Government.

\section{References}

Benke, A. C., A. D. Huryn, L. A. Smock, and J. B. Wallace. 1999. Length-mass relationships for freshwater macroinvertebrates in North America with particular reference to the southeastern United States. Journal of the North American Benthological Society 18:308-343.

Brown, A. M. 1986. Modifying reservoir fish habitat with artificial structures. Pages 98-102 in G. E. Hall and M. J. Van Den Avyle, editors. Reservoir fisheries management: strategies for the 80s. American Fisheries Society, Bethesda, Maryland.

Chick, J. H., and C. C. McIvor. 1997. Habitat selection by three littoral zone fishes: effects of predation pressure, plant density, and macrophyte type. Ecology of Freshwater Fish 6:27-35.

Diehl, S., and P. Eklov. 1995. Effects of piscivore-mediated habitat use on resources, diet, and growth of perch. Ecology 76:1712-1726.

Dodson, S. I., and D. G. Frey. 1991. Cladocera and other Branchiopoda. Pages 723-786 in J. H. Thorp and A. P. Covich, editors. Ecology and classification of North American freshwater invertebrates. Academic Press, San Diego, California.

Downing, J. A., and F. H. Rigler, editors. 1984. A manual on methods for the assessment of secondary productivity in fresh waters. Blackwell Scientific Publications, Oxford, UK.

Gerrish, N., and J. M. Bristow. 1979. Macroinvertebrate associations with aquatic macrophytes and artificial substrates. Journal of Great Lakes Research 5:69-72. 
Glass, N. R. 1971. Computer analysis of predator energetics in the largemouth bass. Pages $325-363$ in B. C. Patten, editor. Systems analysis and simulation in ecology, volume 1. Academic Press, New York.

Gotceitas, V., and P. Colgan. 1989. Predator foraging success and habitat complexity: quantitative test of the threshold hypothesis. Oecologia 80:158-166.

Hall, D. J., and E. E. Werner. 1977. Seasonal distribution of fishes in the littoral zone of a Michigan lake. Transactions of the American Fisheries Society 106:545-555.

He, X., and J. F. Kitchell. 1990. Direct and indirect effects of predation on a fish community: a whole-lake experiment. Transactions of the American Fisheries Society 119:825835.

Horinouchi, M. 2007. Review of the effects of within-patch scale structural complexity on seagrass fishes. Journal of Experimental Marine Biology and Ecology 350:111129.

Hrbáček, J., M. Dvorakova, V. Korinek, and L. Prochazkova. 1961. Demonstration of the effect of the fish stock on the species composition of zooplankton and the intensity of metabolism of the whole plankton assemblage. Verhandlungen Internationale Vereinigung für theoretische und angewandte Limnologie 14:192-195.

Ivlev, V. S. 1961. Experimental ecology of the feeding of fishes. Yale University Press, New Haven, Connecticut.

Jelbart, J. E., P. M. Ross, and R. M. Connolly. 2006. Edge effects and patch size in seagrass landscapes: an experimental test using fish. Marine Ecology Progress Series 319:93-102.

Kimmel, B. L., and A. W. Groeger. 1984. Factors controlling phytoplankton production in lakes and reservoirs: a perspective. Pages 277-281 in Lake and Reservoir Management. U.S. Environmental Protection Agency, Report EPA 440/5/84-001, Washington, D.C.

Lemke, A. M., and A. C. Benke. 2004. Growth, reproduction, and production dynamics of a littoral microcrustacean, Eurycercus vernalis (Chydoridae), from a southeastern wetland, USA. Journal of the North American Benthological Society 23:806-823.

Lima, S. L., and L. M. Dill. 1990. Behavioral decisions made under the risk of predation: a review and prospectus. Canadian Journal of Zoology 68:619-640.

Merritt, R. W., and K. W. Cummins, editors. 1996. An introduction to the aquatic invertebrates of North America, 3rd edition. Kendall/Hunt, Dubuque, Iowa.

Mittelbach, G. G. 1986. Predator-mediated habitat use: some consequences for species interactions. Environmental Biology of Fishes 16:159-169.

Mittelbach, G. G., and P. L. Chesson. 1987. Predation risk: indirect effects on fish populations. Pages 315-322 in W. C. Kerfoot and A. Sih, editors. Predation: direct and indirect impacts on aquatic communities. New England University Press, Hanover, New Hampshire.

Ney, J. J. 1996. Oligotrophication and its discontents: effects of reduced nutrient loading on reservoir fisheries. Pages 285-295 in L. E. Miranda and D. R. DeVries, editors. Multidimensional approaches to reservoir fisheries man- agement. American Fisheries Society, Symposium 16 , Bethesda, Maryland.

Noble, R. L. 1981. Management of forage fishes in impoundments of the southern United States. Transactions of the American Fisheries Society 110:738-750.

Pennak, R. W. 1989. Fresh-water invertebrates of the United States, 3rd edition. Wiley, New York.

Ratcliff, D. R. 2006. Evaluating the effectiveness of grass bed treatments as habitat for juvenile bass in a drawdown reservoir. Master's thesis. Utah State University, Logan.

SAS Institute. 2001. SAS Software, version 8.2 for Windows. SAS Institute, Cary, North Carolina.

Savino, J. F., and R. A. Stein. 1982. Predator-prey interaction between largemouth bass and bluegills as influenced by simulated, submersed vegetation. Transactions of the American Fisheries Society 111:255-266.

Schindler, D. E., and M. D. Scheuerell. 2002. Habitat coupling in lake ecosystems. Oikos 98:177-189.

Sih, A. 1994. Predation risk and the evolutionary ecology of reproductive behavior. Journal of Fish Biology 45(Supplement A):111-130.

Tabor, R. A., and W. A. Wurtsbaugh. 1991. Predation risk and the importance of cover for juvenile rainbow trout in lentic systems. Transactions of the American Fisheries Society 120:728-738.

Tatrai, I., G. Paulovits, K. Matyas, J. Korponai, and P. Pomogyi. 1998. Long-term food web interactions in KisBalaton Reservoir. International Review of Hydrobiology $83: 515-522$.

Tugend, K. I., M. S. Allen, and M. Webb. 2002. Use of artificial habitat structures in U.S. lakes and reservoirs: a survey from the southern division AFS reservoir committee. Fisheries 27(5):22-27.

Vadeboncoeur, Y., M. J. Vander Zanden, and D. M. Lodge. 2002. Putting the lake back together: reintegrating benthic pathways into lake food web models. BioScience $52: 44-54$.

Voshell, J. R., S. W. Hiner, and R. J. Layton. 1992. Evaluation of benthic macroinvertebrate sampler for rock outcrops in rivers. Journal of Freshwater Ecology 7:1-6.

Welschmeyer, N. A. 1994. Fluorometric analysis of chlorophyll $a$ in the presence of chlorophyll $b$ and phaeopigments. Limnology and Oceanography 39:1985-1992.

Werner, E. E., J. F. Gilliam, D. J. Hall, and G. G. Mittelbach. 1983. An experimental test of the effects of predation risk on habitat use in fish. Ecology 64:1540-1548.

Wiley, J. J., R. W. Gorden, S. W. Waite, and T. Powless. 1984. The relationship between aquatic macrophytes and sport fish production in Illinois ponds: a simple model. North American Journal of Fisheries Management 4:111-119.

Wurtsbaugh, W. A., and C. Hawkins. 1990. Trophic interactions of fish and invertebrates in Bear Lake, Utah/Idaho. Ecology Center Special Publication, Utah State University, Logan.

Wurtsbaugh, W. A., and H. W. Li. 1985. Diel migrations of a zooplanktivorous fish (Menidia beryllina) in relation to the distribution of its prey in a large eutrophic lake. Limnology and Oceanography 30:565-576. 